\title{
Non-symbiotic Nitrogen-fixing Organisms from Some New Zealand Tussock-grassland Soils
}

\author{
By M. A. LINE AND MARGARET W. LOUTIT \\ Department of Microbiology, Medical School, University of Otago, \\ Dunedin, New Zealand
}

(Accepted for publication 8 April 197I)

SUMMAR Y

The screening of several hundred isolates from tussock-grassland soils for nitrogen-fixing ability resulted in the isolation of Clostridium butyricum and five facultatively anaerobic nitrogen-fixing species. These latter have been identified as Bacillus circulans (tentative identification), B. polymyxa, Enterobacter aerogenes (formerly Aerobacter aerogenes), Klebsiella pneumoniae and Escherichia intermedia.

Estimates of numbers of these species indicate that they will be responsible for only very low rates of nitrogen fixation in the soils tested.

\section{INTRODUCTION}

Azotobacter and Beijerinckia are found only in isolated localities in New Zealand soils, while nitrogen-fixing clostridia although ubiquitous do not generally occur in large numbers in soils of low fertility (Ross, 1958, I960 a, b, $c$; di Menna, 1966; Nordmeyer, I966; Line \& Loutit, 1969). Since a number of agriculturally important tussock-grassland soils receive little or no addition of nitrogen, we have tried to detect other organisms which might contribute to the nitrogen economy of these soils.

\section{METHODS}

Soils. Soil samples were taken from the Rock and Pillar Range of Central Otago which has a tussock cover dominated by Festuca novae-zelandiae from $300 \mathrm{~m}$. and by Chionochloa rigida at higher altitudes up to $\mathrm{I} 200 \mathrm{~m}$. The soil is a sandy loam, yellow-brown to yellowgrey earth, with $\mathrm{pH}$ values ranging from $4 \cdot 5$ to $5 \cdot 8$. Three sites at altitudes of 500, 700 and $1000 \mathrm{~m}$. were sampled at monthly intervals. Soils were sampled and stored as previously described (Line \& Loutit, 1969).

Media. (i) For the isolation of possible nitrogen-fixing species: the solid and liquid nitrogen-deficient media described by Brown, Burlingham \& Jackson (1962) were modified slightly. Either glucose or sucrose was used as carbon source; the $\mathrm{pH}$ value of the glucose media was adjusted to 7.0 and that of the sucrose media to 6.5 . A third medium (pH 6.8) consisted of the glucose agar with $5 \%(\mathrm{v} / \mathrm{v})$ soil extract (Löhnis, 1920) added and contained not more than $12 \mu \mathrm{g}$. N/ml. Sugars were autoclaved as $50 \%$ solutions and added to media previously autoclaved at $15 \mathrm{lb} / \mathrm{sq}$.in. for ${ }_{5} 5 \mathrm{~min}$. Deionized water, AnalaR reagent grade (British Drug Houses) chemicals and Difco purified agar were used except in media containing soil extract in which distilled water and Davis agar were used. (ii) For the estimation of numbers of nitrogen-fixing species: glucose solid and liquid media were modified to include thiamine and biotin (0.00I g./1. of each), sodium thioglycollate $(0.5 \mathrm{~g} . / 1$.) and $5 \%(v / v)$ soil extract. (iii) For the determination of nitrogen-fixing ability: media used for 
acetylene reduction studies contained (g./l. distilled water): glucose, $10 \cdot 0 ; \mathrm{MgSO}_{4} \cdot 7 \mathrm{H}_{2} \mathrm{O}$, 0.5 ; sodium thioglycollate, 0.5 ; yeast extract, $0.10 ; \mathrm{CaCl}_{2}, 0.07 ; \mathrm{FeCl}_{3}, 0.0 \mathrm{I} ; \mathrm{H}_{3} \mathrm{BO}_{3}, 0.005$; $\mathrm{MnSO}_{4} .4 \mathrm{H}_{2} \mathrm{O}, 0.005 ; \mathrm{Na}_{2} \mathrm{MoO}_{4} .2 \mathrm{H}_{2} \mathrm{O}, 0.005 ; \mathrm{ZnSO}_{4} .7 \mathrm{H}_{2} \mathrm{O}, 0.005 ; \mathrm{CuSO}_{4} .5 \mathrm{H}_{2} \mathrm{O}, 0.004$; $\mathrm{CoSO}_{4} \cdot 7 \mathrm{H}_{2} \mathrm{O}, 0.000025$. Medium for the cultivation of Enterobacter aerogenes and Klebsiella pneumoniae was buffered by $\mathrm{Na}_{2} \mathrm{HPO}_{4}, 13 \cdot 0 \mathrm{NaH}_{2} \mathrm{PO}_{4} \cdot 2 \mathrm{H}_{2} \mathrm{O}, \mathrm{I} \cdot 33$; for the cultivation of Escherichia intermedia and Bacillus polymyxa by $\mathrm{K}_{2} \mathrm{HPO}_{4}, 2 \cdot 0, \mathrm{KH}_{2} \mathrm{PO}_{4}, 0 \cdot 5$; and for the cultivation of Bacillus circulans and Clostridium butyricum by $\mathrm{K}_{2} \mathrm{HPO}_{4}, \mathrm{I} \cdot \mathrm{O}$, $\mathrm{KH}_{2} \mathrm{PO}_{4}, 0.5$. Thiamine and biotin (0.00I of each) were added where required.

With the exception of the buffers the constituents were kept in concentrated sterile stock solutions, with the $\mathrm{FeCl}_{3}$ and glucose sterilized and stored in separate containers. When required, sterile buffer solutions were boiled and cooled to expel dissolved gasses and the other constituents added to give a clear solution suitable for extinction readings.

For total nitrogen determinations of aerobic isolates the glucose medium of Brown et al. (1962) was used, while for known nitrogen-fixing species the same media as used for the acetylene reduction studies were used except the yeast extract concentration was reduced to $0.01 \mathrm{~g}$./l. Determinations of ${ }^{15} \mathrm{~N}_{2}$ uptake were made in the glucose media used for the estimation of numbers of nitrogen-fixing species.

\section{Isolation of possible nitrogen-fixing organisms}

Aerobic isolation. (i) Dilution plating: portions $(0.2 \mathrm{ml}$.) of tenfold serial soil dilutions were spread onto the surface of the glucose, sucrose and soil extract agar plates previously dried for $60 \mathrm{~min}$. at $37^{\circ}$. After 5 days at $28^{\circ}$, all colonies from suitable dilution plates were picked off and grown as separate cultures on nitrogen-deficient agar. (ii) Soil enrichments: quantities of soil $(0.5 \mathrm{~g}$.) were inoculated into shallow layers of glucose and sucrose liquid media in Petri plates and incubated at $28^{\circ}$ for 2 to 4 weeks. A loopful of each culture was then streaked onto the corresponding agar medium and onto $5 \%$ soil extract agar and incubated for a further week.

For isolation of nitrogen-fixing blue-green algae the soil enrichment method described by Allen \& Stanier (1968) and the dilution-plate method described by Jurgensen \& Davey (1968) were used.

Anaerobic isolation. Dilution plates and soil enrichments were prepared as above except that cultures were incubated under nitrogen in an anaerobic jar for I to 2 weeks. Isolates were purified by streaking onto plates followed by incubation under anaerobic conditions.

\section{Acetylene reduction}

Qualitative determinations as an indirect test for nitrogen fixation. Aerobic isolates except for those obtained on soil extract agar were streaked onto slopes of $15 \mathrm{ml}$. of glucose agar medium in $\mathrm{I} \cdot \mathrm{O} \mathrm{oz}$. universal containers and incubated at $28^{\circ}$. Isolates obtained on soil extract agar were streaked onto soil extract agar slopes. When adequate growth appeared (usually after $24 \mathrm{~h}$.) the air was removed by evacuation through injection ports in the caps of the bottles and replaced with a gas phase of cylinder argon $80 \%$, oxygen $10 \%$ and acetylene $10 \%$. After incubation for $24 \mathrm{~h}$. gas samples were removed for testing. Anaerobic samples were tested similarly except that the agar slopes were initially incubated under oxygen-free nitrogen which was replaced by a mixture of cylinder argon $90 \%$ and acetylene I0 \%. The acetylene was scrubbed in concentrated $\mathrm{H}_{2} \mathrm{SO}_{4}$ to remove traces of ammonia and the argon scrubbed in alkaline pyrogallol to remove traces of oxygen. Ethylene was detected on a Pye series 104 gas chromatograph (with flame ionization detector) fitted with a I $52 \times 0.62 \mathrm{~cm}$. column containing $20 \%$ polyethylene glycol adipate on Chromosorb $\mathbf{P}$, 
85 to 100 mesh. The column was run at room temperature with nitrogen as the carrier gas at a flow rate of about $100 \mathrm{ml} . / \mathrm{min}$. The apparatus was run most conveniently at a sensitivity which would detect not less than 2 nmoles ethylene/gas sample, since extensive testing showed no advantage to be gained using higher sensitivities. Positive Beijerinckia or Clostridium controls were run with each test batch. Uninoculated slopes were used as negative controls.

Quantitative determinations. Conical $200 \mathrm{ml}$. side-arm flasks containing $70 \mathrm{ml}$. of sterile medium plus a piece of flamed iron gauze were inoculated, sealed, flushed and filled with nitrogen. Cultures of Bacillus polymyxa were incubated unshaken at $30^{\circ}$ while the rest were gently rocked in a water bath at $30^{\circ}$ with the exception of Escherichia intermedia for which a $25^{\circ}$ water bath was used. Growth was followed in the shaken cultures using an Eel nephelometer. Samples of culture could be removed for testing by withdrawing via a tube passing through the seal into the medium. Duplicate $4 \mathrm{ml}$. samples in $20 \mathrm{ml}$. test tubes were used for determining ethylene production rates. The samples were exposed to a gas phase of acetylene $5 \%$ and argon $95 \%$ after one flushing and were then rocked (with the tubes in a horizontal position) at their original temperatures for one hour. The reaction was stopped by placing the tubes in a boiling water bath. Duplicate gas volumes of $0.5 \mathrm{ml}$. were used for each analysis. The remaining culture was used for dry weight determinations after washing once in distilled water. Alternately if clumping did not occur, dry weights were determined by comparing turbidity measurements with a standard curve. For the determination of rates of acetylene reduction the carrier gas flow rate was set at $40 \mathrm{ml} . / \mathrm{min}$. and ethylene peak areas quantitated using a standard curve.

\section{Identification of isolates and determination of their characteristics}

Isolates were identified to genus with the help of Skerman's key (Skerman, 1967) and to species where possible using Bergey's Manual of Determinative Bacteriology (1957). Optimum temperature for fixation by the isolates was found by comparing ethylene production rates of aliquots of nitrogen-fixing cultures placed in water baths varying at intervals of $2.5^{\circ}$ over a range of $10^{\circ}$. Buffered nutrient broth was used for $\mathrm{pH}$ determinations. Hydrogen sulphide production was tested using triple sugar iron agar. Decarboxylase and dihydrolase reactions for the differentiation of the enterobacteria were tested using the methods of Møller (1955).

Micro-Kjeldahl determination of nitrogen uptake. Twenty-five ml. volumes of nitrogendeficient liquid medium in Petri plates were inoculated with $0.5 \mathrm{ml}$. of a just visible suspension in saline of a young culture and incubated aerobically or anaerobically (under nitrogen) for 7 to 28 days. Azotobacter, Beijerinckia or Clostridium cultures were used as positive controls. Negative control plates were inoculated with $0.5 \mathrm{ml}$. of the stored inoculum immediately prior to testing. Duplicate $10 \mathrm{ml}$. samples were used for micro-Kjeldahl nitrogen analyses as described in Kabat \& Mayer (196r). Glucose utilization was estimated using the method of Somogyi (1952).

Determination of ${ }^{15} \mathrm{~N}_{2}$ uptake. Growing nitrogen-deficient cultures were exposed to a gas mixture of nitrogen $10 \%\left(96\right.$ atom $\left.\%{ }^{15} \mathrm{~N}_{2}\right)$ and argon $90 \%$ for $24 \mathrm{~h}$. at $28^{\circ}$. A Pseudomonas species (isolated from a soil enrichment) was used as a negative control. Parallel cultures were checked for acetylene reduction. Following exposure to ${ }^{15} \mathrm{~N}_{2}$, the cultures were digested, acidified and sent for mass spectrometry analyses to the Department of Scientific and Industrial Research, Institute of Nuclear Sciences, Lower Hutt.

Estimates of numbers of nitrogen-fixing bacteria in the soil. Clostridial numbers were estimated using the methods of Jensen (195I) and of Ross (1958). In the latter method, however, the clostridia were counted after counts were made of other colony types. 
Estimates of other nitrogen-fixing species were made using both dilution plates and a most probable number (MPN) technique based on the reduction of acetylene by nitrogen-fixing bacteria. The dilutions for plates were made as for nitrogen-fixing organisms (four plates per dilution). For the MPN technique $0.1 \mathrm{ml}$. volumes of tenfold dilutions were inoculated into bijoux bottles (Io bottles/dilution for three serial dilutions) containing 2 to $3 \mathrm{ml}$. of the described liquid medium/bottle and an iron nail which had been flamed to red heat and added when cool. Both plates and bottles (loosely capped) were incubated at $28^{\circ}$ in an anaerobic jar for I week. Following incubation the cultures containing clostridia were usually very turbid with considerable froth. From experience these were always positive when tested for acetylene reduction and consequently could be simply checked microscopically, counted and discarded. The remainder were gently shaken and a small amount of each bottle poured into another bijoux containing a slope of nitrogen-deficient agar. These were incubated anaerobically for $48 \mathrm{~h}$. with the caps loose, after which they were tightened and the bottles gassed with acetylene and argon as previously described. Following incubation for a further $24 \mathrm{~h} .0 .5 \mathrm{ml}$. gas samples were tested for ethylene production. For purposes of identification all positive cultures were numbered and streaked onto nitrogen-deficient agar and eosin methylene blue (EMB) agar. The cultures were then heated at $80^{\circ}$ for $10 \mathrm{~min}$. and streaked onto nutrient agar. Nitrogen-deficient agar plates were incubated under nitrogen, while the others were incubated aerobically. Cultures of the three enterobacteria could be readily distinguished and identified on the EMB agar, while the Bacillus species could be distinguished on the nutrient agar. Any previously missed Clostridium species were identified on the nitrogen-deficient agar which also served to provide a stock culture if no identification could be made. Similar methods were used to identify colonies on the dilution plates, except blue-staining Clostridium colonies were counted after flooding the plates with iodine.

\section{Isolation of nitrogen-fixing species}

RESULTS

Aerobic isolates. Possible nitrogen-fixing isolates were first obtained using media and techniques designed to detect Azotobacter (Brown et al. 1962). Variation in the agar medium of carbon source, $\mathrm{pH}$, and type of agar did not result in higher counts from soil samples. Spreading the soil dilution on agar plates gave better results than incorporating the dilution in the plating medium or in a soft agar overlay.

Of a total of 142 isolates obtained from both dilution plates and soil enrichments, 96 were able to survive ten serial transfers on agar medium containing no added source of nitrogen. All but one (a Xanthomonas species) were identified as Pseudomonas. All isolates grew poorly in nitrogen-deficient liquid medium, although most caused an aggregation of the calcium carbonate particles due to some slime production.

No nitrogen fixation could be detected by micro-Kjeldahl analyses, although a Beijerinckia control fixed $2.4 \mathrm{mg}$. N/25 ml. medium. No stimulation of growth or nitrogen fixation was obtained by addition of $0.1 \%$ Difco agar (Jensen, 1956) or $5 \%$ soil extract. Addition of ${ }_{15} \mu \mathrm{g} . \mathrm{N} / \mathrm{ml}$. as $\left(\mathrm{NH}_{4}\right)_{2} \mathrm{SO}_{4}$, although stimulating growth, did not result in nitrogen fixation, nor was any diauxic pattern observed as demonstrated by Procter \& Wilson (1958) and Goerz \& Pengra (196I). None of the isolates reduced acetylene either aerobically or anaerobically.

To test if the isolates had lost their nitrogen-fixing ability due to ageing or transfer a further 229 pseudomonads were isolated aerobically on dilution plates, subcultured and 
tested for acetylene reduction, again with negative results. Fresh isolates from aerobic soil enrichments were also incapable of acetylene reduction.

No blue-green algae were isolated from any of the soils.

Anaerobic isolates. Several hundred isolates obtained from nitrogen-deficient liquid media and dilution plates incubated anaerobically were screened for acetylene-reducing ability. Although many of these were Pseudomonas species which were capable of growth on the deficient media but were incapable of nitrogen fixation, a number of acetylene-reducing

Table I. Characteristics of facultatively anaerobic nitrogen-fixing species

\section{Character}

Gram reaction

Flagella position

Indole

Methyl red

Voges-Proskauer

Citrate utilization

Glucose

Lactose

Sucrose

Salicin

Gelatin hydrolysis

Starch hydrolysis

Casein hydrolysis

Nitrate reduction

$\mathrm{H}_{2} \mathrm{~S}$ production

Capsule formation ${ }^{1}$

Indicator milk

Urease

Catalase

Ornithine decarboxylase

Lysine decarboxylase

Arginine dihydrolase

Optimum temperature ${ }^{2}$

Temperature range

Optimum pH

$\mathrm{pH}$ range

Crystalline dextrins

Biotin requirement

Thiamine requirement

Lecithinase

Growth in $2 \% \mathrm{NaCl}$ broth

Growth on potato

Me.B. reduction

$\begin{array}{ll}\begin{array}{c}\text { Bacillus } \\ \text { circulans }\end{array} & \begin{array}{c}\text { Bacillus } \\ \text { polymyxa }\end{array} \\ - & +\mathrm{v} . \\ \text { peritr. } & \text { peritr. } \\ + & + \\ + \text { w. } & - \\ - & + \\ - & - \\ \text { A } & \text { AG } \\ \text { A } & \text { AG } \\ \text { A } & \text { AG } \\ \text { A } & \text { AG } \\ + & + \\ + & + \\ - & + \\ + & + \\ - & - \\ + & + \\ \text { A } & \text { AC } \\ - & - \\ + & + \\ \text { n.t. } & \text { n.t. } \\ \text { n.t. } & \text { n.t. } \\ \text { n.t. } & \text { n.t. } \\ 28^{\circ} & 30^{\circ} \\ 8^{\circ} \text { to } 39^{\circ} & 8^{\circ} \text { to } 41^{\circ} \\ 6 \cdot 5 \text { to } 7 \cdot 0 & 6 \cdot 5 \text { to } 7 \cdot 4 \\ 5 \cdot 5 \text { to } 7 \cdot 8 & 5 \cdot 2 \text { to } 9 \cdot 2 \\ - & - \\ + & + \\ + & - \\ - & +v \\ - & + \\ \text { sl. } & + \\ + & + \\ & + \\ + & + \\ + & + \\ + & +\end{array}$

Enterobacter
aerogens
-
peritr.
+
-
+
+
AG
AG
AG
AG
+
-
-
+
+
+
AC
-
+
+
+
+
+
$28^{\circ}$
$3^{\circ}$ to $38^{\circ}$
6.0 to $7 \cdot 0$
$5 \circ 0$ to $9 \cdot 4$
n.t.
n.t.
n.t.
n.t.
n.t.
n.t.
n.t.

+

Escherichia pneumoniae intermedia

\begin{tabular}{|c|c|}
\hline- & - \\
\hline $\begin{array}{l}\text { n.m. } \\
+\end{array}$ & $\begin{array}{l}\text { peritr. } \\
+\end{array}$ \\
\hline- & + \\
\hline$+w$. & - \\
\hline+ & + \\
\hline $\mathrm{AG}$ & $\mathrm{AG}$ \\
\hline $\mathbf{A G}$ & $\mathrm{AG}$ \\
\hline AG & $\mathrm{AG}$ \\
\hline$A G$ & $\mathrm{AG}$ \\
\hline- & - \\
\hline- & - \\
\hline- & - \\
\hline+ & + \\
\hline- & - \\
\hline+ & + \\
\hline A & A \\
\hline+ & - \\
\hline+ & + \\
\hline- & - \\
\hline+ & - \\
\hline- & - \\
\hline $30^{\circ}$ & $25^{\circ}$ \\
\hline $10^{\circ}$ to $47^{\circ}$ & $3^{\circ}$ to $37^{\circ}$ \\
\hline $6 \cdot 0$ to $7 \cdot 4$ & 6.5 to 7.0 \\
\hline 3.8 to $10 . \mathrm{I}$ & 4.8 to 9.0 \\
\hline n.t. & n.t. \\
\hline n.t. & n.t. \\
\hline n.t. & n.t. \\
\hline n.t. & n.t. \\
\hline n.t. & n.t. \\
\hline n.t. & n.t. \\
\hline n.t. & n.t. \\
\hline
\end{tabular}

$\mathrm{A}=$ acid; $\mathrm{C}=$ coagulation; $\mathrm{G}=$ gas; $\mathrm{Me.B} .=$ methylene blue; n.m. = non-motile; $\mathrm{n} . \mathrm{t} .=$ not tested; peritr. $=$ peritrichous $;$ sl. $=$ slight $; v_{.}=$variable $; w_{.}=$weak .

1 On nitrogen-deficient agar. ${ }^{2}$ For acetylene reduction.

species were isolated. Of these, only one species, identified as Clostridium butyricum, was strictly anaerobic while the remainder, belonging to five species and two families, were all facultatively anaerobic. These were identified as Bacillus circulans (tentative identification), B. polymyxa, Enterobacter aerogenes, Klebsiella pneumoniae and Escherichia intermedia.

Characteristics of the nitrogen-fixing isolates. Characteristics of the facultatively anaerobic isolates are given in Table I. Additional characteristics are discussed in the text. Isolates identified as Clostridium butyricum are not described in detail since they are well-known soil 
nitrogen-fixers and typical of the species as described in Bergey's Manual. Nitrogen-fixing abilities of the isolates are given in Table 2.

Bacillus circulans (tentative identification). These isolates were similar in most respects to $B$. circulans as described in Bergey's Manual. Additional characteristics not given in Table I were as follows: colonies on nutrient agar were off-white, translucent, slightly raised with a regular edge; isolated colonies showed concentric rings and reached $2.0 \mathrm{~mm}$. diameter, no colony movement was observed; the cells measured 0.5 to $0.7 \times \mathrm{I} \cdot 7$ to $4.8 \mu \mathrm{m}$., spores measured 0.7 to $\mathrm{I} \cdot 4 \times \mathrm{I} \cdot 0$ to $2 \cdot 4 \mu \mathrm{m}$.; cells occurred singly and in chains, showed polar or bipolar metachromatic granules and spored readily on beef-extract agar but poorly on nutrient agar; spores were terminal to subterminal and generally swollen, but both swollen and unswollen spores have been observed on blood agar; growth in nutrient broth was turbid with sediment; no gas was produced from anaerobic nitrate broth; methylene blue was reduced and reoxidized in a few days; $\alpha$ haemolysis was produced on human blood agar.

\section{Table 2. Quantitative determinations of cultures incubated under anaerobic conditions}

Gas mixture for ${ }^{15} \mathrm{~N}_{2}$ uptake contained ${ }^{15} \mathrm{~N}_{2}$ 10\% (96 atoms \%) and argon 90\%, and for acetylene reduction determinations contained acetylene $5 \%$ and argon $95 \%$. Duplicate cultures were used for all determinations. Ethylene production rates given are maximal.

\begin{tabular}{|c|c|c|c|c|c|}
\hline Isolate & $\begin{array}{l}\text { Nitrogen } \\
\text { fixed } \\
(\mu \mathrm{g} . / \mathrm{ml} . \\
\text { medium })\end{array}$ & $\begin{array}{l}\text { Glucose } \\
\text { utilized } \\
\text { (mg./ml. } \\
\text { medium) }\end{array}$ & $\begin{array}{l}\text { mg. N } \\
\text { fixed/g. } \\
\text { glucose } \\
\text { utilized }\end{array}$ & $\begin{array}{c}\text { Atoms } \%{ }^{15} \mathrm{~N}_{2} \\
\text { excess }\end{array}$ & $\begin{array}{c}\text { nmoles } \\
\text { ethylene } \\
\text { produced } / \mathrm{mg} \text {. } \\
\text { dry wt/h. }\end{array}$ \\
\hline $\begin{array}{l}\text { Pseudomonas sp. } \\
\text { (control) }\end{array}$ & 0.0 & n.t. & - & $0.005 \pm 0.001$ & 0.0 \\
\hline Bacillus polymyxa & $53^{\circ} \circ$ & 10.0 & $5 \cdot 3$ & $0.480 \pm 0.016$ & I 20 \\
\hline B. circulans & $3 \cdot 6$ & $\mathrm{I} \cdot 6$ & $2 \cdot 3$ & $0.324 \pm 0.010$ & 50 \\
\hline $\begin{array}{l}\text { Enterobacter } \\
\text { aerogenes }\end{array}$ & 13.5 & $8 \cdot 0$ & $1 \cdot 7$ & $0.408 \pm 0.012$ & 300 \\
\hline $\begin{array}{l}\text { Klebsiella } \\
\text { pneumoniae }\end{array}$ & $35 \cdot 4$ & $9 \cdot 4$ & $3 \cdot 8$ & n.t. & 1400 \\
\hline $\begin{array}{l}\text { Escherichia } \\
\text { intermedia }\end{array}$ & $6 \cdot 0$ & $2 \cdot 4$ & $2 \cdot 5$ & $0.068 \pm 0.002$ & 120 \\
\hline $\begin{array}{l}\text { Clostridium } \\
\text { butyricum }\end{array}$ & $70 \cdot 4$ & $8 \cdot 8$ & $8 \cdot 0$ & n.t. & 850 \\
\hline
\end{tabular}

Bacillus polymyxa. These isolates were as described in Bergey's Manual. A bacteriocin was produced by the isolates against $B$. polymyxa NCTC 10343 .

Enterobacter aerogenes and Klebsiella pneumoniae. Apart from the ability of E. aerogenes to liquefy gelatin and the ability of $K$. pneumoniae to weakly produce indole these isolates were typical of their respective species.

Escherichia intermedia. Characteristics other than those given in Table I were: on nutrient agar colonies were grey, translucent, slightly raised with an irregular transparent edge and reached up to $5 \mathrm{~mm}$. diameter; on EMB agar neighbouring colonies became confluent and showed a greenish metallic sheen by reflected light, by transmitted light colonies exhibited a dark central area surrounded by a pink zone; nutrient broth cultures became turbid with a grey sediment; lactose fermentation was delayed, occurring after 3 days. 


\section{Nitrogen-fixing ability}

Preliminary experiments to determine most suitable media for acetylene reduction studies indicated that the addition of both sodium thioglycollate and iron gauze to the media resulted in higher rates of fixation. An increase in thioglycollate concentration to $\mathrm{I} \cdot \mathrm{O} \mathrm{g} . / \mathrm{l}$. was, however, slightly inhibitory. The buffers used in these media were adopted after it was found that less concentrated buffers did not maintain suitable $\mathrm{pH}$ values. Using the described

Table 3. Estimates of numbers of nitrogen-fixing species/g. oven-dried soil

Sampling $\begin{gathered}\% \text { Soil Jensen's } \mathrm{N}_{2} \text {-fixing Dilution } \\ \text { date } \\ \text { moisture } \overbrace{\text { MPN }}^{\text {Clostridium butyricum }}\end{gathered} \overbrace{\begin{array}{c}\text { Dilution } \\ \text { plates Identification Clostridium) Identification* }\end{array}}^{\begin{array}{c}\mathbf{N}_{2} \text {-fixing } \\ \text { count minus }\end{array}}$
Soil (I), altitude $1000 \mathrm{~m} ., \mathrm{pH} 4.5$

$\begin{array}{lccccccr}\text { 10 Aug. I970 } & 35 \cdot 7 & \text { I2 } & \text { I9 } & \text { I I } & 0 & - & 70 \\ \text { ro Sept. I970 } & 42 \cdot 6 & \text { IOI } & 49 & 5 & 0 & - & \text { I30 } \\ \text { I3 Oct. 1970 } & 38 \cdot 3 & 239 & 32 & 0 & 80 & \begin{array}{c}\text { Enterobacter } \\ \text { aerogenes }\end{array} & \text { I50 } \\ 24 \text { Nov. I970 } & 36 \cdot 0 & \text { n.t. } & 0 & 0 & 5 & \begin{array}{c}\text { Bacillus } \\ \text { polymyxa }\end{array} & 4 \mathrm{I}\end{array}$

Soil (2), altitude $700 \mathrm{~m} .$, pH 5.4

\begin{tabular}{|c|c|c|c|c|c|c|c|c|}
\hline \multirow[b]{2}{*}{ Io Aug. I970 } & \multirow[b]{2}{*}{$29 \cdot 7$} & \multirow[b]{2}{*}{$\mathrm{I}, 280$} & \multirow[b]{2}{*}{ I 37} & \multirow[b]{2}{*}{$\mathrm{I}, \mathrm{I} 44$} & \multirow[b]{2}{*}{0} & \multirow[b]{2}{*}{-} & \multirow[b]{2}{*}{$55 \mathrm{I}$} & \multirow{3}{*}{$\begin{array}{l}\text { B. polymyxa } \\
\text { B. circulans } \\
\text { K. pneumoniae } \\
\text { E. aerogenes } \\
\text { B. circulans }\end{array}$} \\
\hline & & & & & & & & \\
\hline IO Sept. 1970 & $48 \cdot 3$ & 1,600 & I 80 & 1,064 & 32,200 & E. aerogenes & 26,920 & \\
\hline I3 Oct. I970 & $38 \cdot 9$ & 2,170 & 0 & 780 & 16,380 & E. aerogenes & 25,200 & $\begin{array}{l}\text { E. aerogenes } \\
\text { B. circulans }\end{array}$ \\
\hline 24 Nov. 1970 & $28 \cdot 3$ & n.t. & 0 & 860 & $\begin{array}{r}105 \\
50\end{array}$ & $\begin{array}{l}\text { Klebsiella } \\
\text { pneumoniae } \\
\text { E. aerogenes }\end{array}$ & 840 & $\begin{array}{l}\text { K. pneumoniae } \\
\text { E. aerogenes } \\
\text { B. circulans }\end{array}$ \\
\hline
\end{tabular}

\begin{tabular}{|c|c|c|c|c|c|c|c|c|}
\hline 10 Aug. 1970 & $30 \cdot 1$ & 4,576 & 212 & 660 & 0 & - & 245 & $\begin{array}{l}\text { B. polymyxa } \\
\text { B. circulans }\end{array}$ \\
\hline 10 Sept. 1970 & $26 \cdot 8$ & 2,993 & 236 & 5,883 & 0 & - & 69 & $\begin{array}{l}\text { B. circulans } \\
\text { E. aerogenes }\end{array}$ \\
\hline I 3 Oct. 1970 & $3 I \cdot 9$ & 2,640 & 220 & $\mathrm{I}, 177$ & 55 & E. aerogenes & 726 & $\begin{array}{l}\text { E. aerogenes } \\
B \text {. circulans }\end{array}$ \\
\hline 24 Nov. 1970 & $20 \cdot 3$ & n.t. & I IO & 510 & 0 & - & 190 & B. circulans \\
\hline
\end{tabular}

buffers the $\mathrm{pH}$ values of cultures of isolates other than Clostridium butyricum or Bacillus circulans remained between 6.0 and 7.0 at the time of acetylene reduction determinations. Suitable buffers for cultures of the remaining two species which did not inhibit growth while maintaining $\mathrm{pH}$ values have not yet been found.

In common with all other nitrogen-fixing species acetylene reduction by Bacillus circulans and Escherichia intermedia was at least partially inhibited by the addition to the medium of small amounts (10 $\mu \mathrm{g}$. $/ \mathrm{ml}$.) of combined nitrogen as $\left(\mathrm{NH}_{4}\right)_{2} \mathrm{SO}_{4}$.

Estimates of numbers of nitrogen-fixing species. Estimates over a period from late winter 
to early summer are given in Table 3. Estimates of numbers of individual species using the nitrogen-fixing MPN method are difficult to assess due to competition where two or more species occurred in any one culture. The exception was Clostridium butyricum, which overgrew all else and dominated the lower dilutions. Hence in Table 3 the estimates of numbers of Clostridium are given while other species are listed in order of predominance. The sum of the facultative species was estimated by subtracting estimated numbers of Clostridium from the total estimates. The only critical factor in this method is the time given for the growth of the agar slope cultures prior to acetylene exposure. Although preliminary tests using all the above species showed 24 to $36 \mathrm{~h}$. prior incubation gave higher levels of acetylene reduction on testing, $48 \mathrm{~h}$. was chosen so as not to eliminate any possible slower growing organism.

\section{DISCUSSION}

In contrast to the reports of other workers (Paul \& Newton, I96I ; Moore, I963; Meiklejohn \& Weir, 1968) for soils elsewhere, no aerobic nitrogen-fixing Gram-negative bacteria have been detected in the New Zealand soils studied. Ross $(1958 ; 1960 b)$ was also unable to demonstrate significant fixation by similar Gram-negative bacteria isolated from New Zealand tussock-grassland soils.

The copious slime production of the aerobic isolates on nitrogen-deficient agar allowed comparatively few cells to form quite large colonies, leading one to incorrectly suppose they may be obtaining nitrogen by fixation. Instead, the organisms must be able to survive using the traces of combined nitrogen in the media and in the air (Hill \& Postgate, 1969) and the need to assess nitrogen fixation by means other than Kjeldahl has been discussed by these workers.

The absence of blue-green algae from the soils studied was probably due to the low $\mathrm{pH}$ and poor fertility of the soils (Flint, 1958). Similar effects of soil fertility and pH on the occurrence of blue-green algae have been found in other soil habitats (Shields \& Durrell, I964; Jurgensen \& Davey, 1968; Shtina et al. 1968).

From an examination of estimates of numbers of nitrogen-fixing bacteria over a 4 month period it is apparent that a considerable discrepancy is observed between estimates of numbers of clostridia obtained from the nitrogen-fixing MPN as compared with the other two methods. This indicates that a multiple number of clostridial cells are required to initiate growth in the nitrogen-deficient liquid medium, but once growth has started it will continue to heavy turbidity.

Apart from the isolation of Escherichia intermedia from the undiluted soil enrichments, this species was not isolated from either dilution plates or from the diluted MPN soil enrichments. It is concluded that numbers of these bacteria in the soil are very low, although estimated numbers reached $5.0 \times 10^{5}$ to $6.0 \times 10^{5}$ cells/g. soil (oven dried) which had been taken from a marshy stream near the summit of the range. Similarly, although Bacillus circulans was the most consistently encountered species from the MPN cultures this organism was never encountered on dilution plates. All other facultative species appear to be transient in the soil, occurring in significant numbers for only short periods of time.

A MPN method for estimating numbers of anaerobic nitrogen-fixing bacteria based on the reduction of acetylene to ethylene has been described by Campbell \& Evans (1969). The present method differs in the means of obtaining suitable reduced conditions of growth, since instead of ensuring removal of all traces of oxygen by the use of pyrogallol in sidearmed tubes, sodium thioglycollate and heated nails have been employed to provide strong reducing conditions in the medium itself. Since this is considerably simpler to set up it 
would appear to be more practicable where large numbers of cultures are involved. Also a further subculture onto nitrogen-deficient agar slopes was included in the method, thus allowing the acetylene treatment of all cultures together after a $48 \mathrm{~h}$. growth period. The absence of significant growth in many of the nitrogen-fixing liquid cultures made it otherwise impossible to estimate the appropriate time for acetylene exposure.

The use of the described isolation methods has resulted in the detection of two species (Escherichia intermedia and Bacillus circulans) which have not previously been reported to fix nitrogen, while the remaining three facultative nitrogen-fixing bacteria have not been widely reported in earlier studies. Although the $E$. intermedia, due to its delayed lactose fermentation, would be identified as Paracolobactrum intermedium according to the 1957 edition of Bergey's Manual, this character alone has not been generally accepted as sufficient to warrant continued separation of the genus Paracolobactrum from other genera of the family. Bacillus circulans has been described by Smith, Gordon \& Clark (1952) as 'the most difficult to characterize of all the species of the genus'. Whether or not the unusual features of the present isolates (ability to fix nitrogen, variability of spore diameter, lack of milk coagulation and $\alpha$ haemolysis of blood agar) are of sufficient significance to remove them from this species cannot be known until the characteristics of the $B$. circulans group have been satisfactorily defined.

The nitrogen uptake determinations given in Table 2 indicate a low efficiency of fixation for the two new nitrogen-fixing species and for Enterobacter aerogenes. The inconsistent levels of ${ }^{15} \mathrm{~N}_{2}$ uptake shown can be attributed to the medium used, since the more suitable media used for acetylene reduction and total nitrogen determination were not found until after the ${ }^{15} \mathrm{~N}_{2}$ experiment was completed. The figures given, however, do show considerable excess over the 0.015 atoms $\%{ }^{15} \mathrm{~N}_{2}$ level of significance.

Considering the generally low numbers and low efficiency of fixation in culture media by the predominant facultatively anaerobic nitrogen-fixing bacteria, their contribution to the soil nitrogen economy is probably of a very low order.

M. A. L. is a Miss E. L. Hellaby Indigenous Grassland Research Fellow.

\section{REFERENCES}

Allen, M. M. \& Stanier, R. Y. (I968). Selective isolation of blue-green algae from water and soil. Journal of General Microbiology 5r, 203-209.

Bergey's Manual of Determinative Bacteriology (1957), 7th edn. Edited by R. S. Breed, E. G. D. Murray \& N. R. Smith. Baltimore: Williams \& Wilkins Co.

Brown, M. E., Burlingham, S. K. \& JACKSON, R. M. (1962). Studies on Azotobacter species in soil. I. Comparison of media and techniques for counting Azotobacter in soil. Plant and Soil 17, 309-319.

Campbell, N. E. R. \& Evans, H. J. (1969). Use of Pankhurst tubes to assay acetylene reduction by facultative and anaerobic nitrogen-fixing bacteria. Canadian Journal of Microbiology $15,1342-1343$.

Di MENNA, M. E. (1966). The incidence of Azotobacter and of nitrogen-fixing clostridia in some New Zealand soils. New Zealand Journal of Agricultural Research 9, 2 I8-226.

Flint, E. A. (1958). Biological studies of some tussock-grassland soils. IX. Algae: Preliminary observations. New Zealand Journal of Agricultural Research 1, 99I-997.

Goerz, R. D. \& Pengra, R. M. (I96I). Physiology of nitrogen fixation by a species of Achromobacter. Journal of Bacteriology 8x, 568-572.

Hill, S. \& Postgate, J. R. (1969). Failure of putative nitrogen-fixing bacteria to fix nitrogen. Journal of General Microbiology 58, 277-285.

JENSEN, H. L. (195I). Notes on the microbiology of soil from northern Greenland. Meddelelser om Gronland I42, 23-29.

Jensen, V. (1956). Nitrogen fixation by strains of Aerobacter aerogenes. Physiologia Plantarum 9, $130-136$. $2 I$ 
JURGENSEN, M. F. \& DAVEY, C. B. (I968). Nitrogen-fixing blue-green algae in acid forest and nursery soils. Canadian Journal of Microbiology 14, I I 79-1 183.

KABAT, E. A. \& MAYER, M. M. (196r). Experimental Immunochemistry, 2nd edn. Springfield, Illinois: Charles C. Thomas.

LiNe, M. A. \& LoutiT, M. W. (1969). Occurrence of Azotobacter in some soils of South Island, New Zealand. New Zealand Journal of Agricultural Research 12, 630-638.

LöHNIS, F. (1920). Landwirtschaftlich-bakteriologisches Praktikum. 2Aufl. Gebrüder Borntraeger, Berlin.

MeIklejohn, J. \& WeIR, J. B. (1968). Nitrogen-fixers-pseudomonads and other aerobic bacteria-from Rhodesian soils. Journal of General Microbiology 50, 487-496.

Møller, V. (1955). Simplified tests for some amino acid decarboxylases and for the arginine dihydrolase system. Acta pathologica et microbiologica scandinavica 36, I58-172.

MOORE, A. W. (1963). Occurrence of non-symbiotic nitrogen-fixing micro-organisms in Nigerian soils. Plant and Soil r9, 385-395.

Nordmeyer, A. H. (1966). A Study of Micro-organisms in Soils of the Craigieburn Range. Master of Agricultural Science Thesis, Lincoln College, Canterbury, New Zealand.

Paul, E. A. \& Newton, J. D. (I96I). Studies of aerobic non-symbiotic nitrogen-fixing bacteria. Canadian Journal of Microbiology 7, 7-13.

Proctor, M. H. \& WiLson, P. W. (1958). Nitrogen fixation by Gram-negative bacteria. Nature, London I82, 891.

Ross, D. J. (1958). Biological studies of some tussock-grassland soils: V. Non-symbiotic nitrogen-fixing bacteria. New Zealand Journal of Agricultural Research r, 958-967.

Ross, D. J. (1960a). A note on the occurrence of Azotobacter beijerinckii in a market-garden soil. New Zealand Journal of Agricultural Research 3, 137-140.

Ross, D. J. (1960 $b$ ). Biological studies of some tussock-grassland soils. XVI. Non-symbiotic nitrogen-fixing bacteria of two cultivated soils. New Zealand Journal of Agricultural Research 3, 224-229.

Ross, D. J. (1960c). A note on the occurrence of non-symbiotic nitrogen-fixing bacteria in some introducedpasture soils. New Zealand Journal of Agricultural Research 3, 245-249.

ShitldS, L. M. \& DuRRell, L. W. (1964). Algae in relation to soil fertility. Botanical Review 30, 92-128.

Shtina, E. A., Pankratova, E. M., Perminova, G. N., Tretjakova, A. N. \& Yung, L. A. (I968). The distribution and the role of nitrogen-fixing blue-green algae in the soils of the temperate zone of the U.S.S.R. International Congress of Soil Science 9, I5I-I 58.

Skerman, V. B. D. (1967). A Guide to the Identification of the Genera of Bacteria, 2nd edn. Baltimore: Williams \& Wilkins Co.

Smith, N. R., Gordon, R. E. \& Clark, F. E. (I952). Aerobic Sporeforming Bacteria. U.S. Department of Agriculture Monograph $\mathbf{I} 6$.

Somogyi, M. (1952). Notes on sugar determination. Journal of Biological Chemistry 195, 19-23. 